\title{
Development of and Risk Analysis on Regional Construction-purposed Sea Use
}

\author{
Shufen Liu, Jingyi Zhang, Wei Xu \\ National Ocean Technology Center, Tianjin 300112, China \\ 区域建设用海发展现状及风险分析
}

刘淑芬, 张静怡, 徐伟

国家海洋技术中心, 天津 300112, 中国

\begin{abstract}
Regarding regional construction-purposed sea use in China, this paper introduces its status quo from such three aspects as sea use management system, regional distribution and annual changes; analyzes its risk factors and genesis from such three aspects as nature, society and management; presents the current management policies and measures for its risk prevention and control including preparation of plannings, sea use assessment and marine environment evaluation, and; puts forward the proposals to further strengthen its risk prevention and control.
\end{abstract}

Keywords: regional construction-purposed sea use; risk; risk prevention and control

\section{摘要 \\ 本文从区域建设用海管理制度、区域分布和年度变化 3 个方面介绍了我国区域建设用海发展的现状; 从自 然、社会、管理 3 个方面分析了区域建设用海的风险 因素及成因; 并介绍了目前管理部门在区域建设用海 风险防控方面采取的政策措施，包括规划编制、海域 使用论证和海洋环境评价; 在此基础上提出了进一步 加强区域建设用海风险防控的建议。}

关键词：区域建设用海；风险；风险防控

1. 引言

近年来, 沿海各地陆续实施了一些围填海造地工程,
对缓解工业及城镇建设用地供需紧张矛盾、促进地方 经济发展起到了积极作用。但伴随围填海带来的巨大 经济利益, 个别地区在建设用海项目尚不明确和没有 经过充分论证的情况下, 盲目圈占海域, 不仅造成海 洋环境的严重破坏, 也造成了海域资源的极大浪费。 为此, 我国自 2006 年起实施了区域建设用海制度。 所谓区域建设用海是指在同一围填海形成的区域内 建设多个建设项目, 并对区域内建设用海实行总体规 划管理, 其用海面积一般不少于 50 公顷。区域建设 用海制度的管理目的就是要对区域内的建设项目进 行整体规划和合理布局, 确保科学开发和有效利用海 域资源。同时也有利于解决单个项目用海论证可行而 区域整体论证不可行的问题。

\section{2. 我国区域建设用海发展现状}

从 2006 年起, 我国开始实施区域用海规划制度, 至 今, 根据国家海域使用动态监视监测系统统计数据, 已有 80 多个区域建设用海项目获得批准并实施。

\section{1. 基础数据}

从区域建设用海获批面积分布上看, 全国 11 个沿海 省 (区、市) 均有分布, 其中以渤海湾沿岸地区分布 最多, 其中辽宁 19853 公顷, 河北 29336 公顷。从区 域建设用海获批数量上看, 以辽宁、江苏、浙江和福 建较多, 分别为 11、13、15、12 个 (图 1, 图 2)。 2.2. 我国区域建设用海发展年度变化

根据国家海域动态监视监测系统统计信息, 我国区域 建设用海制度自实施以来, 共批复建设 83 个, 总面 积约 12 万多公顷, 2006-2009 年逐年增多趋势, 2012-2016 年呈逐年减少趋势, 其中以 2009 年和 2012 年较多, 分别约为 2.53 多万公顷和 2.51 万公顷, 2015 年最少, 仅有约 2498 公顷, 2016 年截至 5 月底仅有 304 公顷 (图 3)。 
Risk Analysis and Crisis Response in Big Data Era (RAC-16)

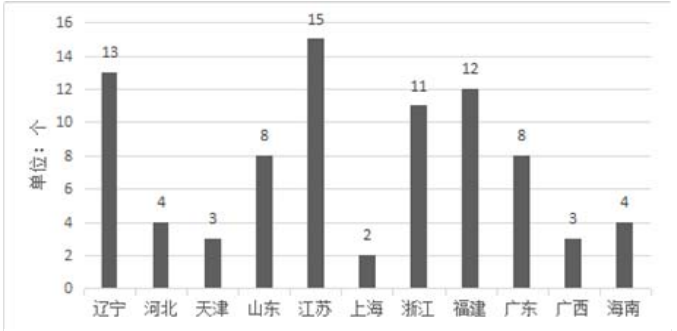

图 1 我国区域建设用海数量统计 (截止 2016.5.30)

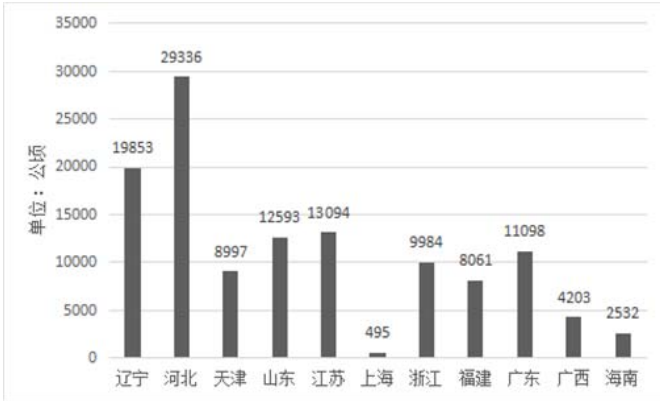

图 2 我国区域建设用海填海面积统计（截止 2016. 5. 30)

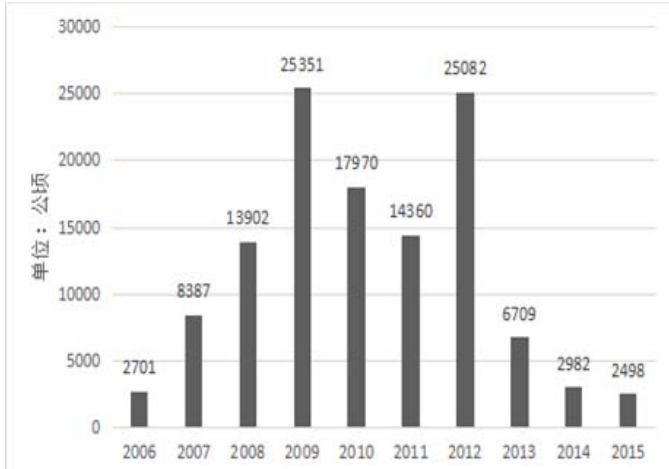

图 3 我国区域建设用海填海面积年度变化

\section{3. 区域建设用海项目特点南北差异明显}

从我国已批复的区域建设用海用途来看, 大部分地区 为了建设工业开发区、滨海旅游区、新城镇和大型基 础设施, 不同区域建设用海用途有较大差异, 总体来 看, 北方地区大部分用作工业与城镇建设, 其用海面 积和填海面积普遍较大; 而南方以港口工业区居多,
其用海面积和填海面积相对较小。险等级图与地市界 线叠加分析, 得到广东各地市的台风风险平均等级, 在此基础上进行空间聚类, 同时结合台风路径频度的 区域规律, 将广东 21 个地市分为 4 个区域, 绘制了 台风风险等级分区图。 


\section{4. 区域建设用海管理现状}

我国自实施区域建设用海制度以来, 国家海洋局相继 出台了一系列针对区域建设用海的管理文件, 主要包 括《关于加强区域建设用海管理工作的若干意见》(国 海发(2006) 14 号)、《区域用海规划编制技术要求》 (国海管字 (2011) 105 号)、《关于规范区域建设用 海规划环境影响评价工作的意见》(国海发 (2011) 45 号), 此外, 还有一些围填海的规范性文件也适用 于区域建设用海管理, 包括《关于改进围填海造地工 程平面设计的若干意见》(国海管字 (2008) 37 号)、 《填海项目竣工海域使用验收管理办法》(国海发 （2007）16 号) 等。从出台的管理政策来看, 我国 的区域建设用海规划偏重于事前管理, 包括规划编 制、平面设计、环境影响评价要求等。

\section{3. 区域建设用海中的风险分析}

\section{1. 自然风险}

海洋灾害。由于区域建设用海的区位特殊性, 相对 于本地区其他区位，区域用海面临着更大的海洋灾害 的威胁。风暴潮、海浪、海啸、海平面上升等都对区 域建设用海带来了巨大的威胁。以海平面上升为例, 根据《2015 年中国海平面公布》, 1980 年至 2015 年 中国沿海海平面上升速率为 3.0 毫米/年, 高于同期全 球平均水平。高海平面将加剧沿海风暴潮、海岸侵蚀、 海水入侵与土壤盐渍化等灾害, 给区域建设用海带来 巨大威胁。

地面沉降。从目前我国围填海形成陆地情况来 看, 填海区地面沉降情况普遍存在。各地新闻多次报 导填海区地面沉降引发纠纷或质疑的案例。如 “深圳 宝安填海区曝'楼陷陷” ” ${ }^{[1]}$, 大连 “东港商务区临海 区观光路局部路段出现裂缝” 等, 更多的填海区地面 沉降没有被报导。实际上, 在目前我国地价高涨的情 况下, 填海建房利益巨大, 受利益驱使, 部分开发商 填海造地之后, 没有经过足够的沉降就建房, 给房屋 安全带来巨大隐患。

生态破坏。填海区对海洋生态环境的改变是颠 覆性和不可逆的, 填海造地不仅破坏了填海区的海洋 生态环境, 还对周边环境产生了恶劣的影响 ${ }^{[2]}$ 。以荷 兰为例, 荷兰地势低凹, 经常遭受风暴、海潮的袭击, 数百年来, 荷兰人筑堤排水、围海造田, 其约 $1 / 4$ 国 土面积是从大海里 “夺” 过来的, 曾被公认是人类战 胜自然的壮举。然而, 随着时间的流逝, 荷兰填海造 地的恶果也开始显现: 湿地丧失、海水污染、生物减 少。为此, 荷兰农业部在 1990 年专门制定了《自然
政策计划》, 又名 “退耕还海计划”, 致力于将现有的 240000 公顷农田恢复为湿地和湖泊。

\section{2. 社会风险}

区域建设用海涉及填海规模大, 工业布局集中, 造成 的人口迁移数量大且影响地区广, 沿海 “一哄而上” 的发展模式会影响我国整个沿海地区的工业布局和 人口发展平衡, 造成沿海地区产业结构趋同, 放大经 济运行风险, 进一步加剧我国人口和劳动力分布和发 展不平衡的问题。[3]

人口发展。城镇建设型和工业聚集型区域建设 用海规划的区别实际并不是特别明显, 很多规模比较 大的工业聚集型区域建设用海, 其中也规划设计了较 大比例的一、二类居住用地。根据《城市用地分类与 规划建设用地标准》(GB50137-2011), “新建城市的 规划人均城市建设用地指标应在 $85.1-105 \mathrm{~m}^{2} /$ 人内 确定”, 根据此标准, 最小规模的区域建设用海其人 口规模也达到了 5000 人, 但实际上, 在已批复的用 途为工业与城镇型区域建设用海规划中, 大部分的规 模都在 $10 \mathrm{~km}^{2}$ 以上, 即, 大部分的工业与城镇型区域 建设用海规划人口规模都应在 10 万人左右。在较短 时间内聚集如此多的人口, 不但会加剧我国人口、劳 动力分布和发展的不平衡, 同时, 能否在短期内完成 迁移也有很大的不确定性。

经济布局。工业聚集型的区域建设用海必然会 对本地甚至一定区域的经济布局和产业结构产生巨 大影响。沿海各地纷纷发展区域建设用海的情况下, 必然带来为招商引资而在项目类型上把关不严等问 题, 进而导致沿海产业布局重复、低效等情况。

\section{3. 管理风险}

由于区域建设用海规模大, 较短时间集中的聚集了大 量的人口, 投入巨额建设资金, 聚集了众多企业, 带 来了巨大的管理风险。

人口管理风险。短期内的大规模人口流动将带来 严峻的城市治安问题、生活配套问题、贫困问题、人 口年龄结构和性别比例等问题。且由于人口体量大, 人口年龄结构单一, 极易将小的问题和风险放大, 产 生群体事件、甚至传染性疾病大规模传播等风险。此 外, 单一的人口年龄结构还不利于区域人口的长期发 展。

城市规划衔接。根据《城乡规划法》规定, 在城 市总体规划、镇总体规划确定的建设用地范围以外, 不得设立各类开发区和城市新区。因此, 城镇建设型 区域建设用海规划的实施, 需要修改城市总体规划。 根据《海域使用管理法》规定, 使用海域首先应当向 


\section{Risk Analysis and Crisis Response in Big Data Era (RAC-16)}

有关海洋行政主管部门提出海域使用申请, 依法取得 海域使用权, 因此, 区域建设用海规划未批准实施, 无法修改城市规划。部门间管理衔接上的问题加剧了 管理上的各种风险。

填海造地建设投资。区域建设用海投资巨大, 动 轩几十亿元, 且填海工程周期较长, 一般需要 3-5 年 甚至更长。因此，区域建设用海的财务管理、融资运 营等面临巨大的风险。以曹妃甸工业区为例, 其规划 面积 380 平方公里, 2003 年启动建设, 目前累计填 海造陆超过 230 平方公里, 总投资超过 3000 亿元, 其每日贷款利息逾千万，面临巨大债务风险。 ${ }^{[4]}$

\section{4. 目前的区域建设用海风险防控管理}

目前对于区域建设用海的风险防控主要集中在区域 建设用海规划编制、海域使用论证和海洋环境评价等 环节。

\section{1. 区域建设用海规划}

国家海洋局出台了《区域用海规划编制技术要求》(国 海管字 (2011) 105 号), 对区域建设用海规划文本 内容、格式和图件等做出了明确要求, 《关于改进围 填海造地工程平面设计的若干意见》(国海管字 (2008) 37 号) 对区域建设用海中围填海的平面设 计也提出了指导性要求。对于区域建设用海规划内容 和围填海平面设计的要求和规范, 使得决策者能够最 大程度获得判断风险的关键信息，也使得规划编制者 重视某些潜在风险因素, 在一定程度上防控风险 ${ }^{[5]}$ 。

\section{2. 海域使用论证和海洋环境评价}

海域使用论证和海洋环境评价制度是针对海域开发 适宜性和海洋环境风险的管理制度。区域建设用海规 模大, 海域开发具有复杂性, 国家海洋局出台了《关 于加强区域建设用海管理工作的若干意见》(国海发 （2006）14 号）和《《关于规范区域建设用海规划环 境影响评价工作的意见》(国海发 (2011) 45 号), 对这两项制度提出了特别的要求, 即, 要求做整体论 证和规划环评。整体论证和规划环评制度的实施, 解 决了单个项目用海论证可行而区域整体论证不可行 的问题，一定程度上降低了区域建设用海的风险。

\section{5. 区域建设用海风险防控建议}

\section{1 加强已有风险防控措施的执行}

现有的区域建设用海整体论证、规划环评，以及对规 划编制和围填海平面设计的要求和规范, 在很大程度 上都是关于区域建设用海风险防控的政策措施, 其实
施效果也很好，应当继续严格执行这些政策措施。

\section{2 统筹规划区域建设用海的发展布局}

国家层面管理部门沟通协调, 根据各地的经济、社会、 人口发展、海域自然条件和开发利用程度，统筹规划 布局全国区域建设用海发展, 最大程度的降低人口迁 移风险, 以及沿海地区产业结构趋同造成的经济风 险。

\section{3 加强区域建设用海管理和城乡发展规划协调}

海洋管理部门、规划部门以及其他政府管理部门就区 域建设用海发展建立协调机制, 从管理上, 集合部门 优势, 形成合力, 防控各类风险。

\section{4 加强区域建设用海技术支撑}

将风险管理理论和技术运用到区域建设用海管理中, 建立区域建设用海的综合风险管理架构 ${ }^{[6][7]}$, 优化决 策。同时运用现代的 “智联网” 技术 ${ }^{[8]}$, 为管理部门 和用海人的决策提供更加全面客观和科学的信息和 决策帮助。

\section{6. 参考文献}

[1] 深圳宝安填海区曝 “楼陷陷”,佛山日报, 2010.4.8

[2] 胡小颖, 周兴华, 刘峰, 彭琳, 辛海英, 杨风丽. 关于围填海造地引发环境问题的研究及其管理 对策的探讨, 海洋开发与管理, 2009.10:80-86

[3] 中国科学院学部. 我国围填海工程中的若干科学 问题及对策建议, 中国科学院院刊, 2011,26 (2): 170-172

[4] 张顺喜. 围海造地工程项目风险管理研究一以曹 妃甸滨海工程为例, 现代商贸工业，2012（2): 35-37

[5] 刘淑芬, 徐伟, 岳奇. 浅谈区域用海的平面设计, 海洋开发与管理, 2012.7: 22-24

[6] 黄崇福, 综合风险管理的梯形架构, 自然灾害学 报, $2005.14(6)$ : 8-14

[7] 黄崇福, 综合风险管理的地位框架设计和多态灾 害链风险分析研究, 应用基础与工程科学学报, 2006.14: 29-37

[8] C.F. Huang, Internet of Intelligences in Risk Analysis for Online Services, Journal of Risk Analysis and Crisis Response, 2011.1 (2): 110-117 